\title{
Intracranial tumour detected on routine parathyroid technetium sestamibi scan
}

\author{
Kanyada Koysombat, ${ }^{1}$ Cecil Eboh, ${ }^{1}$ Nicholas Ashford ${ }^{2}$ Farzad Borumandi ${ }^{3}$
}

'Department of Diabetes and Endocrinology, University Hospitals Sussex NHS Foundation Trust, Worthing Hospital, Worthing, UK ${ }^{2}$ Department of Clinical Radiology and Nuclear Medicine, University Hospitals Sussex NHS Foundation Trust, St Richard's Hospital, Chichester, UK

${ }^{3}$ Department of Oral and Maxillofacial Surgery, University Hospitals Sussex NHS

Foundation Trust, St Richard's Hospital, Chichester and Worthing Hospital, Worthing, UK

\section{Correspondence to} Farzad Borumandi; farzad.borumandi@nhs.net

Accepted 18 April 2021

\section{Check for updates}

(C) BMJ Publishing Group Limited 2021. No commercial re-use. See rights and permissions. Published by BMJ.

To cite: Koysombat K,
Eboh C, Ashford N, et al. BMJ
Case Rep 2021;14:e242480.
doi:10.1136/bcr-2021-
242480

\section{DESCRIPTION}

A 63-year-old woman presented with symptomatic hypercalcaemia, with a calcium level of $2.83 \mathrm{mmol} / \mathrm{L}$ (normal range $2.2-2.6 \mathrm{mmol} / \mathrm{L}$ ) and an inappropriately elevated parathyroid hormone level of $14.6 \mathrm{pmol} / \mathrm{L}$ (normal range $1.6-6.9 \mathrm{pmol} / \mathrm{L}$ ). Calculated urinary calcium:creatinine clearance ratio was 0.0179 , in keeping with a diagnosis of primary hyperparathyroidism (PHPT). Surgical management was considered in the presence of symptoms and osteoporosis denoting end organ damage. Parathyroid scintigraphy was performed with technetium-99m sestamibi (MIBI) scan with early and late planar and single-photon emission CT (SPECT) imaging followed by ultrasound. Besides a left lower pole parathyroid adenoma, left posterior occipital lobe focal MIBI uptake was also demonstrated on the parathyroid scintigram (figure 1). CT and MRI of the brain demonstrated an extra axial, avidly enhancing $17 \mathrm{~mm}$ left occipital tumour diagnostic of a meningioma (figure 2). Following neurosurgical review, in the absence of neurological deficits and lack of clinical and radiological malignant features, a watch-and-wait approach was adopted.

Localisation of parathyroid adenomas reduces operating time and perioperative morbidity following parathyroidectomy. ${ }^{12}$ Parathyroid MIBI scan is the commonly used localisation technique with a reported high sensitivity and specificity of $72 \%$ and $99 \%$, respectively. ${ }^{3}$ MIBI uptake is related to tissue perfusion, cell membrane integrity and mitochondrial activity. ${ }^{4}$ However, the increased radiotracer uptake is not exclusive to the mitochondria-rich oxyphilic cells in parathyroid adenomas. Incidentalomas can be detected with extraparathyroid and extracardiac findings in up to $27 \%$ of studies, the most frequently involving

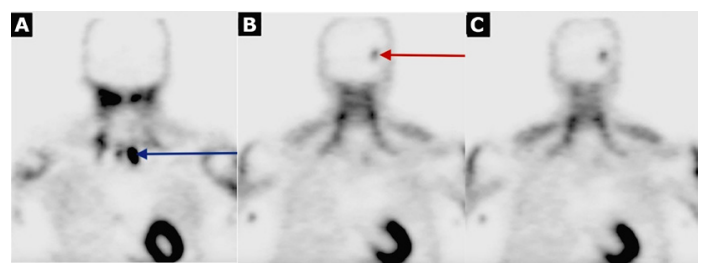

Figure 1 Series of coronal SPECT delayed washout MIBI images, $A$ anterior to $C$ posterior. These demonstrate focal uptake within the left lower pole parathyroid adenoma (blue arrow, image A). The left occipital meningioma is seen as a focal uptake of MIBI on images B (red arrow). and $C$. The uptake in the salivary glands, right axilla, shoulders and neck muscles is expected physiological MIBI uptake and is not pathological. MIBI, Tc $99 \mathrm{~m}$ sestamibi; SPECT, single-photon emission CT.

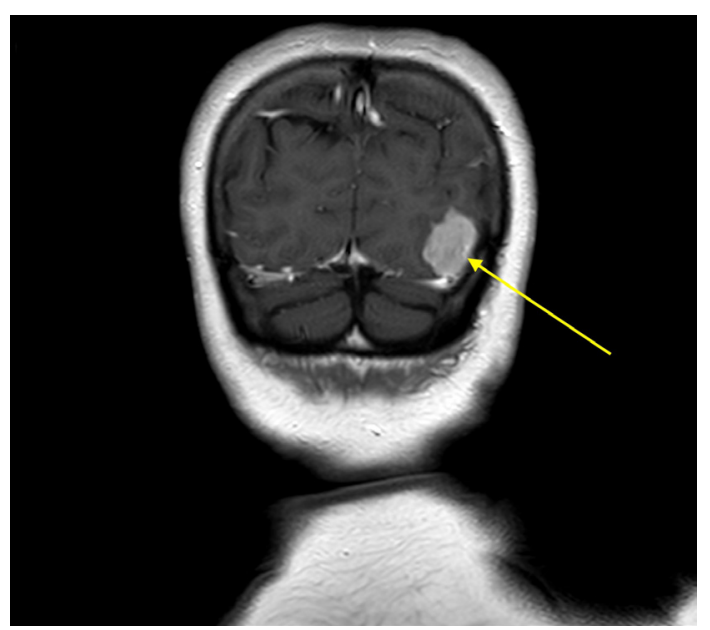

Figure 2 Coronal T1 cranial acquisition MRI after intravenous gadolinium demonstrating an extraaxial lesion in the left occipital region with intense homogenous enhancement confirming the occipital meningioma (yellow arrow).

thyroid and pulmonary tumours. ${ }^{5}$ To the best of our knowledge, this is the first reported case of an incidental meningioma detected on parathyroid MIBI scintigram during localisation of parathyroid tumours.

MIBI uptake in meningiomas is the result of increased mitochondrial activity and perfusion in these tumours. The degree of radiotracers uptake including Thallium-201 and MIBI in meningioma may predict biological aggressiveness of these tumours. ${ }^{4}$ SPECT with MIBI could be used to provide prognostic information as complementary imaging tool for evaluation of meningiomas. ${ }^{4}$ Meningiomas have been reported in conjunction with PHPT both in sporadic cases ${ }^{6}$ and in association with multiple endocrine neoplasia types I and IV with mutations in the genes MEN1 and CDNK1B, respectively. ${ }^{7}$ Although not requiring

\section{Learning points}

- Clinicians need to be vigilant when reviewing technetium-99m sestamibi scans of the head and neck as incidental unrelated tumours can be visible.

- Uptake of technetium-99m sestamibi is not specific for parathyroid tumours/hyperplasia and may be observed in other tumours with increased mitochondrial activity or tissue perfusion like meningioma. 
current neurosurgical management, the incidental detection of meningioma in this case is clinically significant, prompting further endocrinological and genetic investigations. This report aims to raise awareness of non-parathyroid and non-cardiac incidental findings that can be easily missed. This information is important to all clinicians reviewing MIBI scintigrams.

Contributors KK and FB wrote the manuscript. KK performed the literature review. $F B, C E$ and NA provided guidance and edited the manuscript.

Funding The authors have not declared a specific grant for this research from any funding agency in the public, commercial or not-for-profit sectors.

Competing interests None declared.

Patient consent for publication Obtained.

Provenance and peer review Not commissioned; externally peer reviewed.

\section{REFERENCES}

1 Grant CS, Thompson G, Farley D, et al. Primary hyperparathyroidism surgical management since the introduction of minimally invasive parathyroidectomy: Mayo clinic experience. Arch Surg 2005; 140:472-9.

2 Borumandi F, Daultrey H, Laji K, et al. Detectability and surgical outcomes in parathyroid surgery - a single-centre experience. Br J Oral Maxillofac Surg 2019:57:330-5.

3 Lavely WC, Goetze S, Friedman KP, et al. Comparison of SPECT/CT, SPECT, and planar imaging with single- and dual-phase (99m)TC-sestamibi parathyroid scintigraphy. J Nucl Med 2007:48:1084-9.

4 Valotassiou V, Leondi A, Angelidis G, et al. Spect and PET imaging of meningiomas. ScientificWorldJournal 2012:2012:1-11.

5 Mallick R, Malik J, Yip L, et al. Novel findings on SPECT-CT Tc-99 sestamibi imaging for primary hyperparathyroidism. J Surg Res 2020;252:216-21.

6 Poiana C, Carsote M, Popescu A. Primary hyperparathyroidism associated with cerebral meningiomas-Three cases report. ACTA Endocrinol 2007;3:81.

7 Thakker RV. Multiple endocrine neoplasia type 1 (MEN1) and type 4 (MEN4). Mol Cell Endocrinol 2014;386:2-15.

Copyright 2021 BMJ Publishing Group. All rights reserved. For permission to reuse any of this content visit https://www.bmj.com/company/products-services/rights-and-licensing/permissions/

BMJ Case Report Fellows may re-use this article for personal use and teaching without any further permission.

Become a Fellow of BMJ Case Reports today and you can:

- Submit as many cases as you like

Enjoy fast sympathetic peer review and rapid publication of accepted articles

- Access all the published articles

Re-use any of the published material for personal use and teaching without further permission

Customer Service

If you have any further queries about your subscription, please contact our customer services team on +44 (0) 2071111105 or via email at support@bmj.com.

Visit casereports.bmj.com for more articles like this and to become a Fellow 